\title{
Penerapan Metode Mind Mapping untuk Meningkatkan Hasil Belajar PKn Pada Siswa Kelas IX SMPN 1 Kalidawir
}

\author{
Eny Djauharatun Nisak ${ }^{1}$ \\ ${ }^{1}$ SMPN 1 Kalidawir, Tulungagung \\ Email: ${ }^{1}$ enydjauharatun@gmail.com
}

\begin{tabular}{l} 
Tersedia Online di \\
\hline http://www.jurnal.unublitar.ac.id/ \\
index.php/briliant \\
\hline \\
\hline Sejarah Artikel \\
\hline Diterima pada 29 Januari 2018 \\
Disetuji pada 30 Januari 2018 \\
Dipublikasikan pada 13 Februari \\
2018 Hal. 13-24
\end{tabular}

Kata Kunci:

mind mapping, hasil belajar, pkn,

\section{DOI:}

http://dx.doi.org/10.28926/briliant .v3i1.131

\begin{abstract}
Abstrak: Hasil observasi yang dilakukan di Kelas IX A pada waktu pembelajaran Pendidikan Kewaarganegaraan diperoleh hasil belajar siswa kurang memuaskan, yaitu dari 34 siswa hanya 8 siswa yang nilainya dapat mencapai KKM atau 70, sedangkan 26 siswa lainnya masih belum dapat mencapai KKM atau 69. Untuk itu, dilakukan penelitian ini dengan menerapkan metode mind mapping guna menyelesaikan masalah tersebut. penelitian ini merupakan suatu penelitian tindakan kelas dengan subyek siswa kelas IX A SMPN 1 Kalidawir. Adapun materi yang dipilh adalah Peran Indonesia dalam Hubungaan Internasional Dalam Era Globalisasi. Hasil penelitian menunjukkan adanya peningkatan Hasil belajar siswa berdasarkan nilai post test per siklus dengan nilai di atas KKM yaitu persentase pada siklus I 52,9\% dan pada siklus II $88,2 \%$.
\end{abstract}

Pendidikan kewarganegaraan dirumuskan secara luas untuk mencakup proses penyiapan generasi muda untuk mengambil peran dan tanggung jawab sebagai warganegara, dan secara khusus, peran pendidikan termasuk di dalamnya persekolahan, pengajaran dan belajar, dalam proses penyiapan warganegara tersebut. Pendidikan menjadi warga Negara yang memiiliki komitmen yang kuat dan konsisten untuk mempertahankan Negara Kesatuan Republik Indonesia.Hakikat Negara kesatuan Republik Indonesia adalah Negara kesatuan modern. Negara kebangsaan adalah Negara yang pembentuknya didasarkan pada pembentukan semangat kebangsaan dan nasionalisme aitu pda tekad suatu masyarakat untuk membangun masa depan bersama dibawah satu Negara yang sama, walaupun warga masyarakat itu benda-benda agama, ras, etnik, atau golongannya.

Mata pelajaran Pendidikan Kewarganegaran menuntut kemampuan Guru untuk bisa membuat siswa mengerti dan memahami tentang materi yang diajarkan dengan tidak hanya membaca buku dan teori saja melainkan harus diterapkan, keterampilan yang cerdas, terampil, berkarakter yang diamanatkan oleh Pancasila dan UUD 1945. Pendidikan kewarganegaraan yaitu pendididkan yang menyangkut status formal warga Negara yang pada awalnya diatur dalam Undang-Undang No.2 tahun 1949 (Ruminiati, 2008:25).Undang-Undang ini berisi 
tentang diri kewarganegaraan dan peraturan tentang naturalisasi, atau pemerolehan status sebagai warga Negara Indonesia (Ruminiati, 2008:25).

Menurut Zamroni (Tim ICCE, 2005:7) pengertian pendidikan kewarganegaraan adalah pendidikan demokrasi yang bertujuan untuk mempersiapkan warga masyarakat berpikir kritis dan bertindak demokrasi, melalui aktivitas menanamkan kesadaran kepada generasi baru, bahwa demokrasi adalah bentuk kehiduan masyarakat yang palingg menjamin hak-hak warga masyarakat". Diharapkan dapat mempersiapkan peserta didik menjadi warga Negara yang memiliki komitmen yang kuat dan konsisten untuk mempertahankan Negara Kesatuan Republik Indonesia.Hakekat NKRI adalah Negara kebangsaan modern.Tujuan pembelajaran Pendidikan Kewarganegaraan secara umum mempersiapkan generasi bangsa yang unggul dan berkepribadin, baik dalam lingkungan local, regional, maupun global.

Menurut Djamarah (2002:12) proses beajar mengajar adalah suatu proses yang dilakukan secara sadar dan bertujuan. Tujuan ini menjadi arah ke mana proses belajar mmengajar tersebut akan dibawa. Proses belajar mengajar akan berhhasil jika mampu memberikan perubahan dalam pengetahuan, pemahaman, ketrampilan, dan nilai sikap dalam dari siswa.

Walaupun belajar dan mengajar adalah dua hal yang berbeda, keduanya saling berkaitan. Mengajar akan lebih efektif jika kemampuan berfikir siswa diperhatikan. Karena itu perhatian tujuan kepada kesiapan struktur kognitif siswa.Adapun struktur kognitif mengacu pada organisasi pengetahuan atau pengalaman yang telah dikuasai siswa yang memungkinkan siswa itu dapat menangkap konsep-konsep baru termasuk konsep Pendidikan Kewarganegaraan.

Berdasarkan hasil pengamatan dalam proses belajar mengajar dikelas, keadaan sekolah dan melalu peninjauan bidang akademik dan non akademik, diperoleh hasil bahwa keadaan Sekolah Menengah Pertama 1 Kalidawir khususnya siswa kelas IX A tahun ajaran 2015/2016 dalam peajaran pendidikan Kewarganegaran belum menunjukkan hasil belajar sesuai dengan KKM yang ditetapkan terutama pada peran Indonesia dalam hubungan internasional dalam era globalisasi. Padahal, ditinjau dari keadaan fisik sekolah, yaitu ruang keas IX A sudah baik dan sesuai sebagai tempat berlangsungnya proses belajar mengajar. Pengamatan pada proses pembelajaran oleh peneliti dapat disimpulkan bahwa pelaksanaan proses belajar mengajar lah yang belum membuat siswa aktif belajar, sehingga kemampuan siswa belum terganti dengan maksimal.

Pada ulangan hari Pendidikan Kewarganegaraan dengan peran Indonesia dalam hubungan internasional dalam era globalisasi, di dapat ratarata nilai sebesar 62,2 dari 34 siswa, padahal Kriteria Ketuntasan Minimalnya (KKM) telah ditentukan nilai sebesar 70. Dan hanya 8 siswa yang mendapat nilai di atas 70 . Hal ini berarti, hanya $23,5 \%$ dari siswa yang telah mencapai ketuntasan belajar, dan yang lainnya memiliki hasil belajar yang rendah.

Hasil belajar merupakan bagian terpenting dalam pembelajaran. Nana Sudjana (2009:3) mendefisikan hasil belajar siswa pada hakikatnya adalah perubahan tingkah laku sebagai hasil belajar dalam pengertian yang lebih luas mencakup bidang kognitif, afektif, dan psikomotorik. Dimyati dan Mudjiono (2006:3-4) juga menyebutkan hasil belajar merupakan hasil dari suatu interaksi tindak belajar dan tindak mengajar. Dari sisi siswa, hasil belajar merupakan berakhirnya pengajaran dari puncak proses belajar. Hasil belajar yang diteliti 
dalam peneliti penelitian ini adalah hasil belajar kognitif Pendidikan kewarganegaraan yang mencakup tinga tingkat yaitu pengetahuan pemahaman, dan penerapan.

Berdasarkkkan hal tersebut, peneliti meminta bantuan kepada teman sejawat untuk meneliti kekurangan dari pembelajaran yang telah dilaksanakan. Dari hasil diskusi dengan teman sejawatditemukan masalah-masalah dalam proses pembelajaran pendidikan Kewarganegaraan yang menyebabkan menurunkan hasil belajar adalah sebagai berikut: (1) Materi kurang dapat diskusi siswa secara optimal, (2) Siswa belum dapat menyelesaiakan soal peran Indonesia dalam hubungan internasional dalam era globalisasi. (3) Melihat hasil ulangan harian siswa diatas, bisa dilihat jika penggunaan metode pembelajaran dalam pembelajaran Pendidikan Kewarganegaraan pada siswa kelas IX A belum sesuai dan membuat siswa terlihat tidak antusias untuk belajar. (4) Pembelajaran dengan metode konvensional yaitu dengan menjelaskan materi dan siswa hanya melakukan perintah mengerjakan soal tanpa penanaman konsep pembelajaran yang kuat ternyata tidak efektif dalam proses peningkatan hasil belajar siswa.

Oleh karena itu, demi memperbaiki berbagai msalah yang ada, peneliti memerlukan suatu solusi untuk mengatasi hambatan-hambatan yang terjadi. Akhirnya diputusan dengan menggunakan metode mind mapping. Mind map adalah sistem penyimpan, penarikan data, dan akses yang luar biasa untuk perpustakaan raksasa, yang sebenarnya da dalam otak manusia yang menakjubkan (Buzan, 2009:12). Mind Mapping adalah salah satu dari strategi pelajaran yang mengupayakan seorang peserta didik mampu menggali ideide kreatif dan aktf dalam mengikuti kegiatan pelajara. Sehingga pelajaran yang dilakukan akan menjadi lebih hidup, variatif, dan membiasakan siswa memecahkan permasalahan dengan cara memaksimakan yang pikir dan kreatifitas. Dengan demikian tujuan pelajaran yang sudah ditentukan dapat tercapai, dengan metode ini diharapkan hasil belajar siswa dapat meningkat.

Menindaklanjuti permasalahan dan solusi yang ditawarkan maka peneliti tertarik utnuk melakukan suatu penelitian guna ningkatkan hasil belajar siswa kelas IX A di SMP Negeri 1 Kalidawir Tulungagung tahun ajaran 2015/2016 melalui penerapan metode mind mapping. Sehingga tujuan dari penelitian ini adalah mengetahui (1) bagimanakah penerapan metode mind mapping untuk meningkatkan hasil belajar pkn siswa kelas IX A SMPN Kalidawir tahun ajaran 2015/2016, dan (2) apakah metode mind mapping dapat meningkatkan hasil belajar pkn siswa kelas IX A SMPN Kalidawir tahun ajaran 2015/2016.

\section{METODE}

Subjek yang digunakan seluruh siswa kelas IX A Sekolah Menengah Pertama Negeri 1 Kalidawir Tulungagung tahun pelajaran 2015/2016 sebanyak 34 siswa yang terdiri dari 17 siswa putra dan 17 siswa putrid. Lokasi yang digunakan tempat penelitian adalah ruang kelas IX Sekolah Menengah Pertama Negeri 1 Kalidawir Tulungagung tahun pelajaran 2015/2016. Alasan peneliti melasanakan penelitian di tempat tersebut adalah peneliti merupakan salah satu Guru kelas tersebut sehingga memudahkan peneliti alam melaksankan penelitian serta dapat menghemat waktu dan biaya. Penelitian Desain Prosedur Perbaikan Pembelajaran. 
Kegiatan merancang dan melaksanakan perbaikan pembelajaran dengan menerapkan tindakan penelitian kelas akan dilakukan sebanyak 2 siklus, yang dimulai dari refleksi pada sebelum peaksanaan perbaikan pembelajaran dimulai. Namun jika setelah siklus ke-II masih belum menunjukkan adanya peningkatan hasil belajar dan pemahaman siswa, maka akandilakukan sampai siklus ke-III. Berdasarkan hasi pengidentifikasian dan penetapan masalah, penelitian kemudian mengajukan suatu solusi yang berupa penerapan Metode Mind mapping yag dapat dimanfaatkan Guru untuk digunakan sebagai metode pengajaran dalam pembelajaran Pendidikan Kewarganegaraan kelas IX A SMP Negeri 1 Kalidawir Tulungagung.

Kegiatan meancang dan melasanaan perbaikan pembelajaran dengan menerapkan penelitian tindakan kelas sebanyak 2 siklus yang dimulai dari refleksi pada sebelum pelaksanaan perbaikan pembelajaran dimulai. Namun jika setelah diklus ke-II masih belum menunjukkan adanya peningkatan hasil belajar dan pemahaman siswa, maka akan dilanjutkan sebagai siklus ke-III. Berdasarkan hasil pengidentifikasian dan penetapan madalah, penelitan kemudian mengajukan suatu solusi yang berupa Metode mind mapping yang dapat dimanfaatkan Guru ke-III. Berdasarkan hasil pengidentifikasi dan penetapan masalah, peneliti kemudian mengajukan sesuatu solusi yang berupa penerapan Metode mind mapping yang dapat dimanfaatkan Guru untuk digunakan sebagai metode pengajar dalam pembelajaran Pendidikan Kewarganegaraan kelas IX A SMP Negeri 1 Kalidawir Tulungagung.

Peneliti ini dilakukan dengan dua siklus, dimana masing-masing siklus dikenal perlakuan yang sejenis dengan bobot yang beda. Dibuat dua siklus dimaksudkan untuk memperbaiki system pengajaran yang dilaksanakan.

Adapun ragam instrument penelitian tindakan kelas yang telah dipersiapkan yaitu, Rencana Pelaksaan Pembelajaran sebagai instrument rencana pelaksanaan tindakan. Lembah observasi Guru sebagai instrument utama pengumpul pad proses dan lembar observasi siswa, wawancara, angket dan catatan lapangan sebagai instrument pendukung pengumpul data proses. Selain itu juga terdapat instrument pengumpul data hasil, yang dapat dikumpulkan dari hasil belajar berdasarkan sosl-soal yag diberikan, serta ketrampilan siswa berdasarkan rublik yang ada.

Analisis data dari sumber-sumber informasi hasil penelitian di dapat dari: (1) Data hasil observasi keterlaksanaan pembelajaran melalui Meode Mind mapping dan observasi aktivitas siswa dianalisis secara dekriptif untuk memberikan gabaran pelaksanaan pembelajaran dengan menggunakan Metode mind mapping. (2) Analisis Data Wawancara, Hasil wawancara dengan siswa dianalisi secara deskriptif dengan lembar angket untuk mengetahui pendapat Guru dan siswa terdapat pembelajaran (3) Analisis Data Tes Berdasarkan hasil tes siswa, setiapp soal diberi skor kemudian diperoleh nilai untuk setiap siswa.

\section{HASIL}

\section{Siklus I}

\section{Observasi Siswa}

Kegiatan observasi dilaksankan saat pembelajaran Pendidikan Kewarganegaraan berlangsung.Kegiatan observasi difokuskan pada pelaksanaan embelajaran. Dalam kegiatan ini Guru mengamati jalannya pembelajaran. 
Pertama-tama Guru memberikan penjelasan, instruksi atau pertanyaan terhadap peran Indonesia dalam hubungan internasional dalam era globalisasi dalam bentuk soaol. Kedua, Guru mengamati lagkah-langkah kegiatan siswa ketika melakksanakan percobaan sudah sesuaikah langkah yang ditepuh siswa dengan langkah-langkah yang tertera dalam lembar kegiatan. Hasilnya, masih ada kelompok yang terlihatbingung dalam pelaksanaannya, Ketiga, Guru mengamati keaktifan siswa saat melaksankan percobaan, aa beberapa siswa yang tidak aktif dalam melaksanakan percobaan, siswa tersebut hanya berdiam diri seolah-olah tidak mau tahu.

Pengamatan selanjutnya, Guru mengamati bagaimana keaktifan siswa ketika berdiskusi untuk menarik simpulan, ada beberapa siswa yang aktif berargumen dan ada yang berdiam diri saja. Pengamatan yang paling akhir adalah bagaimana kesimpulan hasil diskusi siswa, apakah sesuai dengan hasil pelaksanaan percobaan atau tidak.Dari pengaatan yang terakhir ii ada tiga kelompok yang belum berani mempresentasikan hasil temuan, dan hanya terdapat 3 (tiga) siswa yang mau mengajukan pertanyaan.Hal ini disebabkan, kurangnya petunjuk dan bimbingan dari Guru.

Dari uraian diatas dapat disimpulkan hasil observasi dari siklus I antara lain: (1) Sebagian besar siswa mengerjakan tugas secara berkelompok dengan antusias. (2) Sebagian besar siswa terlibat aktif dalam pembelajaran dengan menggunakan Metode mind mapping. (3) Sebagian besar siswa sudah memperhatikan penjelasn Guru. Hanya ada 5 siswa yang tidak memperhatikan, mereka justru mengajak bicara dengan teman sebangkunya. (4) sebagian besar siswa sudah dapat memahami lembar kegiatan dengan baik, hanya terdaat 5 siswa yang masih bertanya pada Guru tetang peran Indonesia dalam hubungan internasional dalam era globalisasi. (5) baru terdapat sebagaian kecil siswa yang ikut ambil bagian dalam diskusi kelompok. Sebagian besar siswa justru saling berbincang dengan teman duduknya. (6) Terdapat 3 (tiga) kelompok yang melaksanakan diskusi dengan sungguh-sungguh. (7) Dari 6(enam) kelompok, abru terdapat 3 (tiga) kelompok kelompok yag sudah dapat menyelesaikan lembar kegiatan dengan tepat waktu. Sedangkan 3 (tiga) kelompok yang lain berani. (8) Metode pembelajaran dengan memberikan tugas kepada peserta didik untuk mencari kemajuan politik, Ekonomi, Sosial Budaya, Teknologi, dan Hankam. Kemudian siswa mengklasifikasikan, mana yang perlu diambil atau ditiru oleh bangsa Indonesia, mana yang tidak perlu ditiru oleh bangsa Indonesia dirasakan kurang efektif, sehingga waktu yang dialokasikan dalam pembelajaran kurang terlaksana dengan baik. (9) Sewaktu presentasi hasil kelompok dilakukan, hanya terdapat 3 (tiga) dalam menyerap konsep yang diajaran. (10) Masih ada beberapa siswa yang masih tampak bingung dalam melaksankan kegiatan pembelaaran.

\section{Observasi Kegiatan Guru}

Melaksanakan pembelajaran sesuai dengan rencana yang telah disusun. Guru membuka pelajaran dengan baik, mengabsen siswa dan menyampaikan tujuan pembelajaran. Menjelaskan tentang pembelajaran dengan Metode mind mapping. Karena masih baru di perkenalkan oleh siswa, beberapa siswa masih tampak bingung.Mengamati jalannya proes pembelajaran dan menilai kemampuan siswa dalam menyelesaikan tugas dalam kelompoknya.Aktif membimbing siswa. Selama diskusi berlangsung Guru berkeliling mengawasi, membimbing dan 
menjelaskan kepada optimal. Selain itu, Guru juga memotivasi siswa agar melakukan diskusi dengan baik. Guru mengevaluasi dengn baik. Guru memotivasi siswa yang merasa malu untuk maju presentasi hasil temuan.

Dalam pelaksanaan pembelajaran, Guru masi menghadapi berbagai kenndala, anatara lain: (1) Masih ada kelompok yang bingung dalam mengikuti langkah-langkah yang tertera dalam lembar kegiatan. (2) Masih ada beberapa siswa yang belum aktif dalam pelaksanaan percobaan. (3) Ketika pelaksanaan diskusi diskusi, ada beberapa siswa yang tidak aktif menyampaikan pendapatnya. (4) Dalam menyimpulkan hasil percobaan, tersebut terdapat 3 (tiga) kelompok yang malu untuk presentasi, dan hanya terdapat 3 (tiga) siswa yang mengajukan pertanyaan.

Adapun prosentase hasil observasi dalam pelaksanaan percobaan pada siklus I dapat dilihat dari tabel 3 di bawah ini.

Tabel 1 Prosentase Hasil Observasi Siklus I

\begin{tabular}{|c|l|c|}
\hline No & Kegiatan Siswa & Prosentase \\
\hline 1 & Kelengkapan menyiapkan alat dan bahan percobaan & $40 \%$ \\
\hline 2 & Keruntutan langkah-langkah dalam pelaksanaan kegiatan percobaan & $55 \%$ \\
\hline 3 & Keaktifan siswa selama melakukan kegiatan percobaan & $47 \%$ \\
\hline 4 & Keaktifan siswa dalam mengutarakan pendapat saat berdiskusi & $53 \%$ \\
\hline 5 & Kesimpulan akhi sesuai percobaan & $49 \%$ \\
\hline
\end{tabular}

Hasil post test pada siklus pertama dapat menjadi perhitungan prosentase peningkatan hasil beajar siswa.Dengan acuan penilaian tetap berdasarkan nilai KKM yang telah ditetapkan yaitu paling sedikit siswa memperoleh 70. Adapun rekapitulasi hasil test siklus I adalah sebagai berikut:

Tabel 2 Hasil Post Test Siklus Pertama

\begin{tabular}{|c|l|c|}
\hline No & Deskripsi & Nilai \\
\hline 1 & Jumlah Nilai & 2450 \\
\hline 2 & Rata-rata Hasil Post Test & 72,1 \\
\hline 3 & Jumlah siswa yang mendapat nilai diatas KKM (70) & 18 \\
\hline 4 & Presentase siswa yang mendapat nilai diatas KKM (70) & $52,9 \%$ \\
\hline 5 & Jumlah siswa yang mendapat nilai dibawah KKM (70) & 16 \\
\hline 6 & Presentase siswa yang mendapat nilai dibawah KKM (70) & $47,1 \%$ \\
\hline
\end{tabular}

Nilai rata-rata hasil post test, dapat dihitung dari :

$X \frac{\sum x}{\sum N}$, jadi $X \frac{2450}{34}=72,1$ sedikit,

Nilai $\mathrm{KKM}=70$, jadi sudah ada peningkatan hasil belajar, namun hanya

Rumus Ketuntasan Individu (hasil belajar Siswa) =

¿ siswa yang mendapat nilai $\geq 70$

$\sum$ siswa 
Jadi, Ketuntasan Individu (asil belajar siswa) $=\frac{18}{34} \times 100 \%=52,9 \%$

Masing kurang dari indicator pencapaian siklus I sebesar $85 \%$ atau lebih.Maka dilanjutkan percobaan pembelajaran dengan metode mind mapping group pada siklus II.

Tabel berikut adalah daftar frekuensi nilai post test siklus I Pendidikan Kewarganegaraan peran Indonesia dalam hubungan internasional dalam era globalisasi dengan soal pengerjaan siswa kelas IX A SMP Negeri 1 Kalidawir Tulungagung setelah pembelajaran menggunakan Metode mind mapping, dengan nilai minimal KKM sebesar 70:

Tabel 3 Daftar Nilai Ulangan Harian Siklus I

\begin{tabular}{|l|l|l|}
\hline Nilai & Frekuansi & Prosentase \\
\hline $0-40$ & 0 & $0,0 \%$ \\
\hline $41-69$ & 16 & $47,1 \%$ \\
\hline $70-100$ & 18 & $52,9 \%$ \\
\hline Jumlah & 34 & $100 \%$ \\
\hline
\end{tabular}

Dari tabel diatas dapat kita lihat terdapat 16 siswa atau $47,1 \%$ yang mendapat nilai antara 41- 69, dan 18 siswa atau 52,9\% yang mendapat nilai $70-$ 100. Dengan ketentuan nilai KKM 70, dapat disimpulkan jika pencapaian presentasi nilai 70-100, maka hasil belajar siswa telah meningkat dari 23,5\% menjadi 52,9\%. Namun karena belum mencapai target indicator pencapaian siklus I sebesar $85 \%$ atau lebih, maka akan dilanjutkan ke Siklus II.

Selain itu, dari proses wawancara diperoleh kesimpulan bahwa beberapa siswa menjadi bersemangat dalam belajar Pendidikan Kewarganegaran, karena pelaksanaan belajar pendidkan Kewarganegaraa dengan metode mind mapping dilaksanakan dengan langsung secara mandiri oleh siswa secara, dan melaksanakan kegiatan bersama kelompok sehingga lebih ringan. Dari hasil post test, 18 nilai siswa telah sesuai KMM atau diatas nilai 70. Sedangkan 16 siswa dari 34 siswa berhasil.Karena nilai siswa berbeda di bawah 70.Siswa yang mendapat nilai dibawah.

\section{SIKLUS II}

Sama dengan pelaksanaan observasi siklus I, kegiatan dilaksankan saat proses belajar Pendidikan Kewarganegaraan berlangsung. Kegiatan observasi difokuskan pada pelaksanaan pembelajaran. Pertama, dalam kegiatan ini Guru mengamati jalannya pembelajaran.

Kedua Guru mengamati langkahlangkah kegiatan siswa ketika melaksankan percobaan sudah sesuaikah langkah yang diempuh siswa dengan langkahlangkah yang tertera dalam lembar kegiatan. Siklus II ini Guru telah member bimbingan kepada kelompok-kelompok yang mengalami kesulitan pada siklus I untuk menerapakan langkah-langkah pembelajaran dan dapat menjalankan kegiatan sesuai dengan lembar kegiatan yang tersedia.

Ketiga, Guru mengamati keaktifan siswa saat melaksanakan percobaan. Pada sikls II ini kebanyakan siswa telah aktif dalam mengikuti pelaksanaan percobaan, hanya terdapat 34 siswa yang terlihat mengobrol ataupun berdiam diri. 
Pengamatan selanjutya, Guru mengamati bagiamana keaktifan siswa ketika berdiskusi untuk menarik kesimpulan.

Pengamatan yang paling akhir adalah bagaimaa kesimpulan hasil diskusi siswa, apakah sesuai dengan hasil pelaksanaan percobaan atau tidak.Dari pengamatan yang terakhir ini, degan adanya reward yang diberikan oleh Guru, semua kelompok berani mepresentasikan hasil temuannya, dan ternyata terdapat 3-4 siswa saja yang kurang aktif dalam diskusi. Dari uraian di atas dapatt disimpulkan hasil observasi dari siklus II antara lain (1) sebagian besar siswa mengerjakan tugas secara kelompok dengan antusias. (2)Sebagian besar siswa terlihat aktif dalam pembelajaran dengan menggunakan metode mind mapping dengan cara siklus II. (3) hampir semua siswa sudah memeprhatikan penjelasan Guru. Hanya 3-4 siswa yang tida memperhatikan, mereka justru mengajak bicara dengan teman sebangkunya ataupun melamun. (4) Dengan adanya reward, terdapat sebagian besar siswa yang ikut ambil bagian dalam diskusi kelompok. Sebagian kecil siswa masih tampak saling berbincang dengan teman duduknya ataupun melamun.Diskusi dilakukan dengan baik. 6 (enam) kelompok yang terbagi, mereka sudah dapat enyelesaikan Lembar kegiatan dengan tepat waktu.Siswa yang terlihatlemah pada siklus I, lebih banyak mendapat pethatian dan bimbingan dari guru. (5)Dengan adanya reward, 6 (enam) kelompok sudah berani mempresentasikan hasil temuan kelompoknya. Mereka tampak detail dalam memperesentasikan hasil temuananya. (6) Metode pelaksanaan pembelajaran metode mind mapping dengan mencari dari berbagai buku sumber yang ada mengenai praktik pelaksanaan politik luar negeri RI pada masa Orde Lama. Bersama-sama dengan kelompok, siswa saling berdiskusi dan membuat rumusan dalam bentuk skema ataupun table untuk presentasi tersebut terlihat lebih efektif. (7) Sewaktu presentasi hasil kelompok dilakukan, dengan adanya reward, hampir semua siswa mengajukan pertanyaan, hanya terdapat 3-4 siswa yang masih maslu mengajukan pertanyaan. Sehingga dapat disimpulkan bahwa penerapan metode Mind maping siklus II ini maksimal dalam menyerap konssep yang diajarkan.(8) hasil post test menunjukkan hasil belajar siswa pun meningkat.

Pergantian pelaksanaan pembelajaran Metode mind mapping dilaksankan degan baik. Melaksankan pembelajaran sesuai dengan rencana pembelajaran yang telah disusun. Guru membuaka pelajaran dengan baik, mengabsen siswa dan menyampaikan tujuan pembelajaran. Menjelaskan kembali tentang pembelajaran dengan Metode mind mapping. Karena teah dikenalkan sebelumnya maka siswa telah memahami konsep dengan baik. Mengamati jalannya proses pembelajaran da menilai kemampuan siswa dalam menyelesaikan tugas dalam kelompoknya. Aktif membimbing siswa. Selama diskusi berlangsung Guru berkeliling mengawasi, membimbing dan menjelskan kepada siswa atau kelompok yang memerluan penjelasan akan temuannya, agar hasil yang dicapai lebih optimal. Selain itu, guru juga memotivasi siswa agar melakukan diskusis lebih baik lagi dan memberikan reward bagi mereka yang aktif. Guru juga memotivasi siswa agar menyuluruh salah satu siswa untuk memotivasi siswa yang measa malu untuk maju presentasi hasil temuan dan memberikan reward bagi mereka yang berani tampil presentasi.

Dalam pelaksaanan proses pembelajaran, Guru telah melaksankan perbaikan dari siklus I, siswa sudah mengalami kemajuan dan pelaksanaan-pun telah berjalan baik. Namun guru menemukan masalah baru dalam pelaksanaan 
siklus II, yaitu: (1) Referensi yang akan digunakan untuk mencari praktik pelaksanaan politik luar negeri pada masa orde lama terbatas (2) Masih terdapat 34 siswa yang malu dalam presentasi dan kurang aktif dalam diskusi kelompok.

Adapun prosesntase hasil observasi dalam pelaksanaan percobaan pada siklus II dapat dilihat dari tabel di bawah ini.perhitungan prosentase keberhasilan siklus II di bawah ini diskusiskan juga dengan teman sejawat.

Tabel 4 Prosentase Hasil Observasi Siklus II

\begin{tabular}{|c|l|c|}
\hline No & Kegiatan Siswa & Prosentase \\
\hline 1 & Kelengkapan menyiapkan alat dan bahan percobaan & $85 \%$ \\
\hline 2 & Keruntutan langkah-langkah dalam pelaksanaan kegiatan percobaan & $92 \%$ \\
\hline 3 & Keaktifan siswa selama melaksanakan kegiatan percobaan & $90 \%$ \\
\hline 4 & Keaktifan siswa dalam mengutarakan pendapat saat berdiskusi & $88 \%$ \\
\hline 5 & Kesimpulan akhir sesuai percobaan & $89 \%$ \\
\hline
\end{tabular}

Hasil post test pada siklus dapat menjadi perhitungan presentase peningkatan Hasil belajar siswa.Dengan acuan penilaian tetap berdasarkan nilai KKM yang telah ditetapkan yaitu paling sedikit siswa memperoleh nilai 70 . Adapun rekapitulasi hasil test siklus II dalah sebagi berikut :

Tabel 5 Hasil Post Test Siklus Kedua

\begin{tabular}{|l|l|l|}
\hline No & Deskripsi & Nilai \\
\hline 1 & Jumlah Nilai & 2765 \\
\hline 2 & Rata-rata Hasil Post Test & 81,3 \\
\hline 3 & Jumlah siswa yang mendapat nilai diatas KKM (70) & 30 \\
\hline 4 & Presentase siswa yang mendapat nilai diatas KKM (70) & $88,2 \%$ \\
\hline 5 & Jumlah siswa yang mendapat nilai dibawah KKM (70) & 4 \\
\hline 6 & Presentase siswa yang mendapat nilai dibawah KKM (70) & $11,8 \%$ \\
\hline
\end{tabular}

Nilai rata-rata hasil post test, dapat dihitung dari :

$X \frac{\sum x}{\sum N}$, jadi $X \frac{2765}{34}=81,3$ signifikan,

Nilai $\mathrm{KKM}=70$, jadi sudah ada peningkatan hasil belajar, namun hanya

Materi Ketuntasan Individu (hasil belajar Siswa) =

¿ siswa yang mendapat nilai $\geq 70$ $\sum$ siswa $x 100 \%$

Jadi, Ketuntasan Individu (asil belajar siswa) $=\frac{30}{34} \times 100 \%=88,2 \%$

Telah mencapai indicator pencapaian siklus II sebesar $85 \%$ atau lebih. Maka perlu dilanjutkan percobaan pembelajara dengan metode mind mapping pada siklus III. 
Tabel berikut adalah daftar frekuansi nilai post test siklus II Pendidikan Kewarganegranan SMP Negeri 1 Kalidawir Tulungagung setelah penjelasan menggunakan metode mind mapping siklus II dengan nilai minimal KKM sebesar 70:

Tabel 6 Daftar Nilai Ulangan Harian Siklus II

\begin{tabular}{|l|l|l|}
\hline Nilai & Frekuansi & Prosentase \\
\hline $0-40$ & 0 & $0,0 \%$ \\
\hline $41-69$ & 4 & $11,8 \%$ \\
\hline $70-100$ & 30 & $88,2 \%$ \\
\hline Jumlah & 34 & $100 \%$ \\
\hline
\end{tabular}

Dari tabel diatas kita lihat terdapat 4 siswa atau $11,8 \%$ yang mendapat nilai antara 41-69, dan 30 siswa atau 88,2\% yang mendapat nilai antara 70-100. Dengan ketetuan nilai KKM 70, dapat disimplka jika pencapaian presentasi nilai 70-100, maka hasil belajar siswa telah meningkat dari 52,9\% menjadi 88,2\%.dengan $85 \%$ MakaTelah Tercapai ndicator Pencapainan Siklus II Sebesar yang $85 \%$ atau lebih, makatidak perlu dilanjutkan ke Siklus III.

Selain itu, dari proses wawancara diproleh kesimpulan bahwa beberapa siswa menjadi bersemangat dalam belajar Pendidikan Kewarganegaraan, karena pelaksanaan kegiatan belajar Pendidikan Kewarganegaraan dengan Metode mind mapping ini dilasanakan dengan secara baik bersama kelompok menjadikan mereka lebih rieks dan ringan dalam mengerjakan laporan kegiatan. Meskipun masih terdapat kendalakendala seperti yang telah diuraikan dalam laporan observasi.dari hasil post test, 30 nilai siswa telah sesuai KKM atau diatas nilai 70 . Sedangkan 4 siswa dari 34 siswa belum berhasil.Karena nilai siswa berada di bawh 70.Siswa yang mendapat nilai dibawah 70 .

\section{PEMBAHASAN}

Berdasarkan hasil pelaksanaan pada siklus I, II dapat dinyatakan bahwa peningkatan kualitas pembelajaran yang tampak dan diperoleh hasil evaluasi dan keaktifan siswa.

Dari data siklus I hasil observasi menunjukkan, prosesntase keberhasilan kelengkapan menyiapkan alat dan bahan percobaan 40\%, prosentase keruntutan langkah-langkah yang ditempuh dalam pelaksanaan percobaan $55 \%$, prosentase keaktifan siswa dalam melaksanakan kegiatan percobaan 47\%, prosentase keaktifan siswa dalam mengutarakan pendapat saat berdiskusi $53 \%$ dan prosentase hasil penarikan keseimpulan akhir sesuai percobaan $49 \%$.

Berdasarkan data siklus II hasil observasi menunjukkan, prosentase keberhaisllan metode kelengkapan menyiapkan alat dan bahan percobaan siswa yang disiapkan $85 \%$ prosentase keruntutan langkah-langkah yang ditempuh dalam pelaksanaan percobaan $92 \%$, prosentase keaktifan siswa dalam melaksanakan kegiatan percobaan $90 \%$, prosentase keaktifan siswa dalam mengutarakan pendapat saat berdiskusi $88 \%$ dan prosentase hasil penarikan kesimpulan akhir sesuai percobaan $89 \%$.

Dari data diatas juga dapat dilihat adanya prosentase kenaikan nilai Pendidikan Kewarganegaraan mulai dari kondisi awal pra tindakan, diketahui baru 8 siswa atau $23,5 \%$ yang mengalami ketuntasan belajar dan mendapatkan 
nilai sesuai dengan KKM. Hasil evaluasi siklus I menunjukkan baru 18 siswa atau $52,9 \%$ yang mengalami ketuntasan belajar dan mendapat nilai sama dengan atau di atas KKM yaitu 70. Hal itu menunjukkan bahwa pelaksanaan siklus I belum mencapai keberhasilan karena indicator pencapaiannya adalah sebesar $85 \%$ atau lebih. Siklus II menunjukkan ada 30 siswa atau 88,2\% dari 34 siswa yang mengalami ketuntasan belajar. Sehingga peneliti menyimpulkan bahwa pada siklus II ini peneliti telah mencapai keberhasilan dari penelitian tindakan kelas yang telah dilakukan.

Ketika pelaksankan siklus I, peneliti mengalami berbagai kendala antara lain beberapa siswa dalam anggota kelompok masih tampak bermainmaian. Masih ada beberapa siswa belum efektif dalam pelaksanaan percobaan. Ketija pelaksanaan diskusi, adaberapa siswa yang tidak aktif menyampiakan pendapatnya.Dalam menyimpulkan hasil percobaan, terdapat 3 (tiga) kelompok yang malu untuk presentasi, dan hanya terapat 3 (tiga) siswa yang mengajukan pertanyaan.

Peneliti keudian melaksanakan siklus II sebagai perbaikan siklus I, sebelum pelaksanaan siklus II ini peneliti mengganti renaca pembelajaran Metode mind mapping baru, yaitu dengan mencari dari berbagai buku sumber yang ada mengenai praktik pelaksanaan politik luar negeri RI pada masa Orde Lama. Bersama-sama dengan kelompok, siswa saling berdiskusi dan membuat rumusan dalam bentuk skema ataupun table untuk presentasi.Dalam pelaksanaan percobaan, peneliti senatiasa membberi bimbingan untuk siswa dalam melaksankan langkah-langkah sesuai lembar kegiatan. Peneliti pun member bimbingan siswa saat berdiskusi untk menarik kesimpulan. Dengan adanya motivasi guru berupa reward, siswa telah terlihat aktif dalam kegiatan pembelajaran dalam melaksankan percobaan, presentasi di depat kelas dan berdiskusi menarik kesimulan. Meskipun ada kendala yaitu referensi yang akan digunakan untuk mencari praktik pelaksanaan politik luar negeri pada masa orde lama terbatas, namun dengan hasil belajar yang dicapai dapat disimpulkan bahwa penelitian tindakan kelas dari sikuls II ini telah berhasil.

\section{KESIMPULAN}

Berdasarkan hasil penelitian kelas dan telah dilaksankan dalam 2 siklus dengan menerapkan Metode mind mapping dalam pembelajaran Pendidikan Kewarganegaraan pada siswa kelas IX A, dapat dibuat kesimpulan sebagai berikut: Penerapan Metode mind mapping dapat meningkatkan Hasil Pendidikan Kewarganegaraan siswa IX A SMP Negeri 1 Kalidawir Tulungagung.

\section{SARAN}

Berdasarkan hasil penelitian maka ada beberapa yang dapat diperguakan sebagai bahan pertitimbangan dan sebagai bahan uraian penutup penelitian tidanakan kelas ini, antara lain: (1) Bagi Guru, mempersiapkan secara cermat perangkat pendukug pembelajaran dan fasilitas belajar yang diperlukan, karena sangat mempengaruhi efektifitas dan efiisiensi pembeajaran yang pada akhirnya berpengaruh pada proses dan hasil belajar Pendidikan Kewarganegaraan siswa. (2) Bagi Siswa, hendaknya ikut berperan aktif dalam prose pembelajaran, selalu mmengerjakan tugas-tugas yang diberikan guru dan meningkatan usaha beajar sehingga dapat memperoleh prestasi yang diharapkan. (3) Bagi sekolah, 
mengupayakan pengadaan berbagai media pembelajaran Pendikan Kewarganegaraan untuk kelas rendah, baik bantuan maupun swadaya sekolah, sehingga lebih menunjang dalam penanaman konsep-konsep Pendidikan Kewarganegaraan secara lebih nyata sekaligus meningkatkan aktivitas belajar siswa.

\section{DAFTAR RUJUKAN}

Buzan, Tony. 2009. Buku Pintar Mind Maps. Jakarta: Gramedia.

Dimyati \& Mudjiono. 2006. Belajar dan Pembelajaran. Jakarta: Rineka Cipta.

Djamarah, Syaiful Bahri, 2002. Psikologi Belajar. Jakarta: Rineka Cipta.

Pemendiknas Nomor 22 Tahun 2006 tentang Standar Isi. Kementerian Pendidikan Nasional RI.

Ruminiati. 2008. Pengembangan Pendidikan Kewarganegaraan Jakarta: Departemen Pendidikan Nasional.

Sudjana, Nana. 2009. Penilaian Hasil Proses Belajar Mengajar. Bandung: Remaja Rosdakarya.

Tim ICCE. 2005. Pendidikan Kewarganegaraan: Demokrasi, Hak Assasi Manusia dan Masyarakat Madani. Jakarta: Prenada Media. 